\title{
CULTURAL EMPLOYMENT BY LEVEL OF EDUCATION
}

\author{
Diana Sava ${ }^{1 *}$, Alina Badulescu ${ }^{2}$ \\ ${ }^{1}$ Doctoral School of Economic Sciences, Faculty of Economic Sciences, University of \\ Oradea, Oradea, Romania \\ ${ }^{2}$ Department of Economics and Business and Doctoral School of Economics, Faculty of \\ Economic Sciences, University of Oradea, Oradea, Romania \\ diannasava@yahoo.com \\ abadulescu@uoradea.ro
}

\begin{abstract}
The sector of the creative economy brings benefits to the economy, more exactly, through the cultural sector, due to the unlimited resources needed to develop - the human resources represented by their mind or talent. The industrial development and innovation lead towards many changes in the cultural industries mostly due to the digitization effect, an irreversible change in the creation of various cultural goods and services, resulting even new cultural domains and also new regulation in the cultural field. The goods and services produced by the new cultural sector "encompass artistic, aesthetic, symbolic and spiritual values (...) their system of valorisation, which includes a characteristic irreproducible, is linked to its appreciation or pleasure" makes them different from other goods and services as Throsby mentioned (UNESCO, 2009:22). This paper aims to show some positive impacts of the creative economy, highlighting social and economic aspects, such as cultural diversity, tolerance, freedom of expression of the cultural identity and by the other hand, new jobs for artists, earnings' increases, creative clusters, cultural employment etc. We will also show more clearly the activities and the occupations which concern the cultural employment and figures regarding cultural employment in Europe.
\end{abstract}

Keywords: cultural industries, cultural occupations, cultural employment, level of education.

JEL classification: J21, J24, O14.

\section{Introduction}

The significance of the culture cannot be denied, but it is difficult to assess. Although, history showed us that those nations with a well-established culture (i.e. the Romans, the Greeks) enjoyed a higher standard of living. The foundation of a society is represented by culture, as it is recognised that "culture is a thousand facets process through which the elementary and naïve activity of the human race becomes reflexive knowledge and, at its highest level, reaches science and philosophy and finally, pure sense. The external shape the culture takes, reporting to the state and religion, is the society" Burckhardt (Boudon, 1997:524). This aspect is present in our days, also. Nowadays, culture can be approached by the economic science through the eye of the creative economy, a new economic trend which regards economic development exploring talent and intellectual capital.

According to the definition given by UNCTAD, the creative economy represents:

"the interface between creativity, culture, economics and technology as expressed in the ability to create and circulate intellectual capital, with the potential to generate

\footnotetext{
* Corresponding Author: Diana Sava
} 
income, jobs and export earnings while at the same time promoting social inclusion, cultural diversity and human development" (Newbigin, 2010: 24).

Regarding the economic development, we could say, as Newbigin (2010: 24) has pointed out,

"excellence in artistic expression, abundance of talent, and openness to new influences and experimentation are not the privileges of rich countries (...) these sources of creativity can open up new opportunities for developing countries".

The emergence of this new economic sector doesn't significantly influence only the human resources involved, but it has an economic and a social impact because

"the real significance of the creative industries lies not only in their economic value, or even in their wider social and cultural impact, but in that they provide a template for the way in which other economic sectors need to change if they are to survive and prosper in the digital age" (Newbigin, 2010: 28).

\section{Social and economic implications of the creative economy}

The role of the creative economy regards sustainable economic development, social development of communities and exploitation of artistic and intellectual capital available to the national economies (Badulescu, 2007; Badulescu and Badulescu, 2014; Badulescu and Vancea, 2013; Mester et al, 2008), both as human resources and as well, as cultural heritage. Besides its specific characteristics, the creative economy presents also several positive effects on the social and economic life; according to UNESCO the most important positive effects concerning economics (Creative Economy Report 2013: 128-129) are the following:

- Local production of cultural goods and services;

- New jobs available for artists and creative workers;

- Increases of the creative workers' incomes;

- Increases of the total exports due to the export of cultural goods and services;

- Entrepreneurship development: increases in the number of SMEs and start-up companies;

- The emergence of creative clusters;

- Investments in certain regions because of their cultural attractiveness;

The implications mentioned above will be reflected in the rising living standards of the region where the creative sector is growing, but aspects of a better life are felt also socially due to the following effects (Creative Economy Report 2013: 129):

- Social cohesion and cultural diversity;

- Security, tolerance and openness for social interaction;

- Freedom of expression of cultural identity;

- Increases in the number of people involved in the artistic skills formation as recreational or extracurricular activity.

\section{Culture - the tool for shaping the society}

Nowadays, despite that terrorism, poverty, global hunger, limited resources and crime organization are the major problems that our world faces, culture cannot be forgotten. All these problems are directly related to culture, often the money - hunger being hidden behind the mask of the culture, i.e. terrorist attacks. Culture dictates various social practices within a specific group representing "the values of individuals, their own aesthetic and philosophical representations and, at a more collective level, all the ways of understanding a people's identity" (ESSnet Report, 2012: 41). 
For centuries culture showed the level of civilization and the social behaviour of a society, considering its definition, culture has the same roots as the word civilization and both encompass "sciences, beliefs, arts, morals, laws, habits and all the others skills acquired by a human as a member of a society" Tylor (Boudon, 1997:531). Society dictates all the formal and informal trends, as well, starting with the compulsory rules and ending with fashion, music, slang and daily habits. Most of them represent a social inheritance, inherited from the previous generations, as culture.

Nowadays, through culture can be seen the status of society and its social life, as well, dictating the ruling habits summed up as all the "knowledge, attitudes and behavioural common models a society's member have and transmit" (Linton, in Boudon, 1997:532). But the economic and social power of the culture can be manifested as (UNESCO, 2009: 11-12):

- Ownership of the local community of cultural assets able to sustain local development produced by the local cultural industries;

- Gender equality due to the inclusion of young people and women, as knowledge transmitters, in the work field of the cultural sector;

- Local development through family or small businesses.

Culture is the long-term runner for development. Also culture can be seen both as cause and as effect of the economic development; as cause of the economic development - it is the source of generating employment and revenues and as effect - due to peoples' habits of spending on culture when the incomes are higher.

\section{Creative economy through cultural industries}

The term of cultural industries regards the cultural production and consumption, those industries whose main aim is to manufacture and trade products and services with symbolic or expressive role, "which, at the time they are considered as a specific attribute, use or purpose, embody or convey cultural expressions, irrespective of the commercial value they may have" (UNESCO, 2005).

If we want to assess the value of the cultural industries, we have to know exactly what these cultural industries are and what they do. These industries encompass cultural and artistic values, are represented by cultural activities which "include market or non-market oriented activities, with or without a commercial meaning and carried out by any kind of organisation (individuals, businesses, groups, institutions, amateurs or professionals)" (ESSnet CULTURE European Statistical System Network on Culture - Final Report, 2012:20).

In the academic literature and not only, there are many classifications of the cultural industries, as part of the creative economy, but the common features of them regard (ESSnet - CULTURE European Statistical System Network on Culture - Final Report, 2012: 41-42):

- Creativity;

- Intellectual property: trademarks, patents, industrial designs and copyrights;

- Method of production (concerns reproducibility, the hazard of meeting demand on the market or not);

- Use value (intrinsic or symbolic value).

Mainly, the cultural industries focus on film and video, video games, music, TV and radio, books and publishing (O'Connor, 2010:58), specific activities with specific goods and services. 


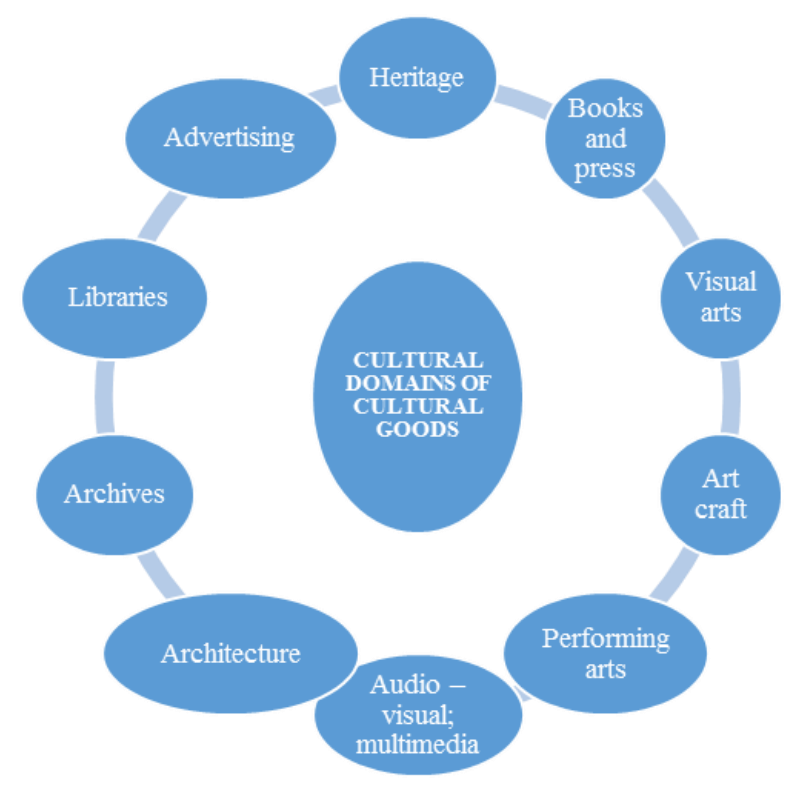

Figure 1: Cultural domains producing cultural goods

Source: realised by the author using data from http://ec.europa.eu/eurostat/cache/metadata/en/cult_trd_esms.htm accessed on 28.03.2017

A cultural domain "consists of a set of practices, activities or cultural products centred around a group of expressions recognized as artistic ones" (ESSnet - CULTURE European Statistical System Network on Culture - Final Report, 2012: 55). The up-mentioned domains are producers of cultural goods identified and ranked by the amount of artistic creation and also, by their artistic, symbolic, aesthetic and spiritual expression. The groups of cultural goods used in the statistics regard "antiques and collectors' pieces; works of art; photography; musical instruments; fabrics (tapestries, embroidery and knitted and crocheted fabrics); books; newspapers, journals and periodicals; maps; developed films and video games; recorded media; architecture plans and drawings" (EUROSTAT, online). These cultural activities of the ten cultural domains are also mapped by six different functions:

- Creation: regards activities related to the elaboration of artistic ideas, contents and original cultural products;

- Production/Publishing: activities, which help turn an original work into an available work;

- Dissemination/Trade: making available artistic creations to consumers by broadcasting, exhibitions, etc.;

- Preservation: protecting and conserving cultural heritage;

- Education: cultural education through formal and informal transferring skills activities;

- Management/Regulation: concerns the means and environments specific to the cultural activities made available by different institutions and organisations.

\section{The cultural employment}

The cultural employment regards all those persons with a cultural occupation, conducting creative and artistic activities included in the economic cycle as "creation, production, dissemination and trade, preservation, education, management and regulation, as well as 
heritage collection and preservation" (ESSnet - CULTURE European Statistical System Network on Culture - Final Report, 2012: 144).

According to the literature of specialty, cultural employment is met in three different situations (ESSnet - CULTURE European Statistical System Network on Culture - Final Report, 2012: 141):

- Employees developing a certain cultural activity in the cultural sector, such as musicians;

- Employees conducting a certain cultural activity but in a different sector;

- Employees conducting non-cultural activities in the cultural sector.

Being employed in the cultural sector means that the tasks needed to be accomplished have a purpose of artistic expression, create, develop or preserve cultural significances or produce cultural goods and services protected by copyrights.

For a better understanding of the cultural occupations, we should consider the following table with a synthesis of the cultural classes.

Table 1: Synthesis of the cultural occupations

\begin{tabular}{|c|c|}
\hline Cultural & occupations \\
\hline $\begin{array}{l}\text { Advertising and public } \\
\text { department managers }\end{array}$ & Sociologists, anthropologists \\
\hline $\begin{array}{l}\text { Sport, recreation and cultural centre } \\
\text { managers }\end{array}$ & Journalists, authors and related writers \\
\hline Building and landscape architects & Translators, interpreters and other linguists \\
\hline Product and garment designers & Visual arts \\
\hline Town and traffic planners & Musician, singer \\
\hline Graphic and multimedia designers & Dancers and choreographers \\
\hline $\begin{array}{l}\text { Primary, secondary, vocational, university } \\
\text { and higher education teachers }\end{array}$ & $\begin{array}{l}\text { Film, stage and related directors and } \\
\text { producers, actors }\end{array}$ \\
\hline Archivists and curators & $\begin{array}{l}\text { Announcers on radio, TV and other media, } \\
\text { broadcasting and audio-visual technicians }\end{array}$ \\
\hline $\begin{array}{l}\text { Librarians and relation information } \\
\text { professionals }\end{array}$ & Photographers \\
\hline Interior designers and decorators & and library technicians \\
\hline Musical instruments makers and tuners & ecious-metal workers \\
\hline Travel guide & $\begin{array}{l}\text { Potters, glass makers, cutters, grinders and } \\
\text { finishers }\end{array}$ \\
\hline $\begin{array}{l}\text { Sign writers, decorative engravers and } \\
\text { etchers }\end{array}$ & $\begin{array}{l}\text { Handicraft workers in wood, basketry, } \\
\text { textile, leather and related materials }\end{array}$ \\
\hline
\end{tabular}

Source: ESSnet - CULTURE European Statistical System Network on Culture - Final Report, 2012: 158

\section{The cultural employment in Europe}

Taking into consideration only an aspect of the development of the creative economy through the cultural activities, we shall show some figures regarding cultural employment in Europe. Some of the chosen countries have economies similar to the economy of Romania, meanwhile other countries play the role model. The analysed period of time starts with 2008 and ends in 2014.

The following table concerns the total amount of people employed in the cultural sector. As it can be noticed the most important economies of Europe have also the highest figures in cultural employment and also these countries met during the period of analysis a constant 
growth. It is important to consider that these years followed the beginning of the economic crisis, and the relevant aspect is that the powerful economies bloomed in these years, whereas the developing economies of Europe decreased in this sector. The reason could be the low demand for the cultural products and services during harder times for those economies where the disposable income is much lower than in the developed economies, and as it is known the cultural products and services satisfy superior needs which are not pretty compatible with the situation of an economic crisis.

Table 2: Cultural employment in Europe (percentage)

\begin{tabular}{|l|c|c|c|c|c|c|c|}
\hline Country / year & $\mathbf{2 0 0 8}$ & $\mathbf{2 0 0 9}$ & $\mathbf{2 0 1 0}$ & $\mathbf{2 0 1 1}$ & $\mathbf{2 0 1 2}$ & $\mathbf{2 0 1 3}$ & $\mathbf{2 0 1 4}$ \\
\hline EU & 2.27 & 2.28 & 2.31 & 2.57 & 2.60 & 2.61 & 2.64 \\
\hline Bulgaria & 2.32 & 2.24 & 2.04 & 1.89 & 1.92 & 1.89 & 1.93 \\
\hline Germany & 2.46 & 2.50 & 2.61 & 3.08 & 2.93 & 2.89 & 2.89 \\
\hline Hungary & 2.43 & 2.20 & 2.31 & 2.60 & 2.65 & 2.70 & 2.51 \\
\hline Ireland & 2.43 & 2.23 & 2.35 & 2.3 & 2.24 & 2.32 & 2.45 \\
\hline Italy & 2.21 & 2.04 & 2.11 & 2.44 & 2.51 & 2.43 & 2.40 \\
\hline Netherlands & 2.99 & 3.04 & 3.25 & 3.44 & 3.54 & 3.71 & 3.71 \\
\hline Norway & 2.75 & 3.00 & 3.08 & 3.5 & 3.72 & 3.64 & 3.36 \\
\hline Romania & 1.21 & 1.11 & 1.01 & 1.05 & 1.15 & 0.97 & 1.11 \\
\hline U.K. & 2.71 & 3.04 & 3.02 & 2.99 & 3.16 & 3.3 & 3.37 \\
\hline
\end{tabular}

Source: EUROSTAT (2016)

What is interesting to notice is that these figures represent mostly people with high formal education, confirming that "culture keeps its full unitary character: culture belongs to the upper classes" (Boudon, 1997:541) and it takes willingness to be acquired. The figure below highlights the necessity of higher education in order to perform in the cultural sector.

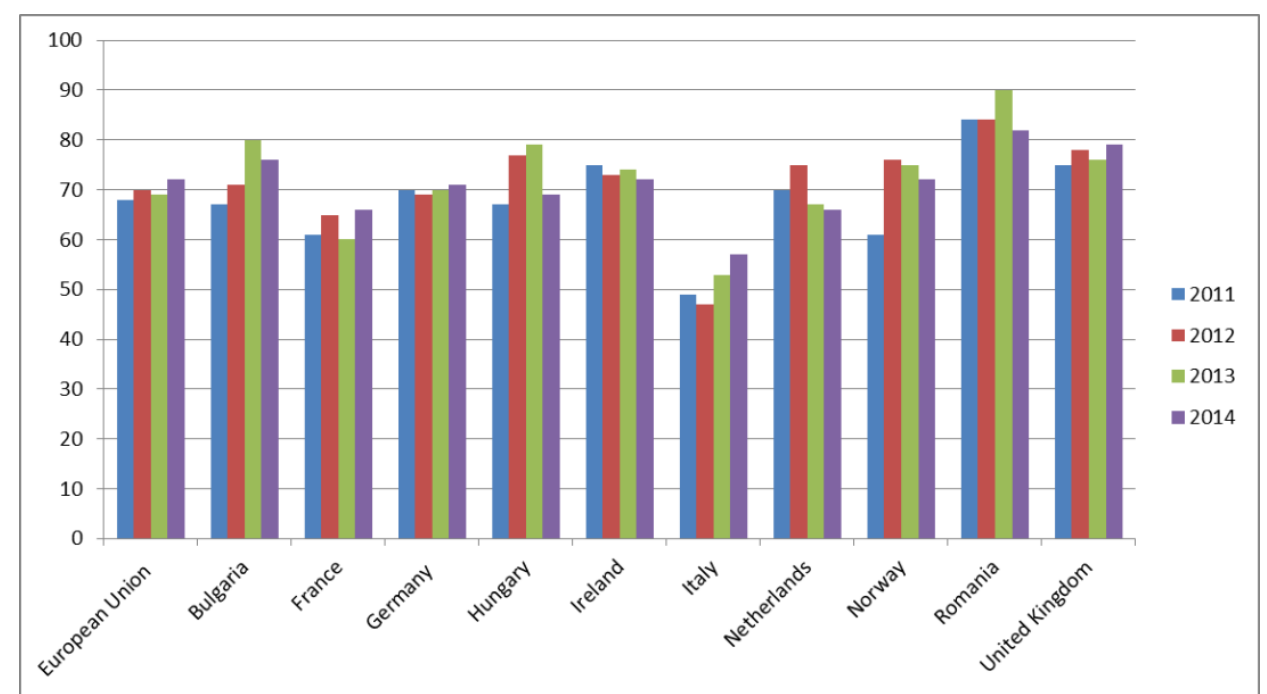

Figure 2: Individuals with high formal education employed as creative and performing artists (percentage)

Source: EUROSTAT (2016)

What is more interesting is that the highest percentages of higher education graduates belong to those European countries which have the lowest number of cultural workers. This 
fact could be related to the different educational systems but also could be seen as a necessity of higher education in the developing countries.

\section{Conclusion}

Tradition, habits and attitudes are related to cultural values through which a person belonging to a social group differs from another, whereas the identity of a group is given by its intrinsic values and a mixture of them frames the culture of group.

Culture frames the higher levels of societies and nowadays the developed economies.

Behind all these social aspects of the culture, culture through the creative economy makes some differences in economic terms, such as the employment.

As mentioned in the academic literature (ESSnet Report, 2012: 42), the activities included in the cultural sector have some particularities given by the cultural expressions, theirs roots in creation and communication through symbols and also, intellectual property rights, represent a useful way of protection for the authors of the cultural goods and services. The cultural sector employs mostly persons with creativity and artistic skills and not only, we should consider the people working in the support activities, as well.

As it was noticed, in several European countries the number of the cultural sector's employees depends on how rich is a country's economy and this also impacts the fluctuation of the cultural employment during the analysed period of time.

But culture is vast, emotional and pretty unknown, too complicated to be fully measured as economic significance.

\section{References}

Badulescu, D. (2007) Globalizarea și băncile. Editura Economică, Bucureşti.

Badulescu, D. and Badulescu, A. (2014) "Medical Tourism: Between Entrepreneurship Opportunities and Bioethics Boundaries", Iranian Journal of Public Health, vol. 43(4), pp. 406-415.

Badulescu, D. and Vancea, M. (2013) Entrepreneurship as Future Career for Post-Graduate Business Students: A Realistic Option?, $8^{\text {th }}$ European Conference on Innovation and Entrepreneurship, 19-20 September, Brussels, Belgium, Proceedings of ECIE 2013, vol. 2, pp. 827-830.

Boudon, R. (1997) Tratat de sociologie, Humanitas, Bucuresti.

ESSnet - CULTURE European Statistical System Network on Culture - Final Report (2012)

[Online], available from: http://ec.europa.eu/culture/library/reports/ess-net-report en.pdf [29.03.2017].

EUROSTAT (2016), [Online], available from:

http://ec.europa.eu/eurostat/cache/metadata/en/cult trd esms.htm

http://appsso.eurostat.ec.europa.eu/nui/show.do?dataset=cult emp sex\&lang=en,

http://appsso.eurostat.ec.europa.eu/nui/show.do?dataset=cult emp artpc\&lang=en

[28.03.2017].

Mester, I., Badulescu, A., Bac, O. and Bac, D. (2008). Qualitative and quantitative analysis of the sport tourism from the perspective of Romanian young adults, https://mpra.ub.uni-muenchen.de/7641/.

Newbigin, J. (2010) The creative economy: An introductory guide, British Council's Creative and Cultural Economy Series, [Online], available from: http://creativeconomy.britishcouncil.org/media/uploads/files/English GuideToolkit 30 with Cover LR.pdf [15.03.2017].

O'Connor, J. (2010) The cultural and creative industries: a literature review - Second edition, Creativity, Culture and Education Series, [Online], available from: 
http://www.creativitycultureeducation.org/wp-content/uploads/CCE-lit-review-creative-cultur al-industries-257.pdf [29.03.2017].

UNESCO (2005), Convention on the Protection and Promotion of the Diversity of Cultural Expressions [online] available from: http://portal.unesco.org/en/ev.php-URL ID=31038\&URL DO=DO TOPIC\&URL SECTION $=201 . \mathrm{html}[01.04 .2017]$

UNESCO (2009) The 2009 UNESCO framework for cultural statistics (FCS), [Online], available

http://www.uis.unesco.org/culture/Documents/framework-cultural-statistics-culture-2009-en .pdf

UNESCO (2013) Creative Economy Report 2013 Special Edition - Widening local development pathways, [Online], available from: http://academy.ssc.undp.org/GSSDAcademy/Upload/CER13_Report_web_optimized.pdf [01.04.2017].

\section{Bio-note}

Diana Sava is PhD student at the Doctoral School of Economic Sciences, University of Oradea. Her research interests include economics of cultural and creative industries.

Alina Bădulescu is professor of Economics, member of the Department of Economics and Business and PhD supervisor at the Doctoral School of Economics, University of Oradea. Her research interests include economics of services and tourism and economics of entrepreneurship. 